
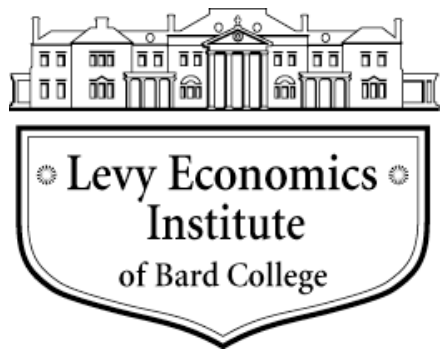

Working Paper No. 870

\title{
Unemployed, Now What? The Effect of Immigration on Unemployment Transitions of Native-born Workers in the United States
}

by

\section{Fernando Rios-Avila}

Levy Economics Institute of Bard College

Gustavo Canavire-Bacarreza

Universidad EAFIT, Colombia, and Institute for the Study of Labor (IZA), Germany

August 2016

The Levy Economics Institute Working Paper Collection presents research in progress by Levy Institute scholars and conference participants. The purpose of the series is to disseminate ideas to and elicit comments from academics and professionals.

Levy Economics Institute of Bard College, founded in 1986, is a nonprofit, nonpartisan, independently funded research organization devoted to public service. Through scholarship and economic research it generates viable, effective public policy responses to important economic problems that profoundly affect the quality of life in the United States and abroad.

Levy Economics Institute P.O. Box 5000

Annandale-on-Hudson, NY 12504-5000

http://www.levyinstitute.org

Copyright (C) Levy Economics Institute 2016 All rights reserved 


\begin{abstract}
Although one would expect the unemployed to be the population most likely affected by immigration, most of the studies have concentrated on investigating the effects immigration has on the employed population. Little is known of the effects of immigration on labor market transitions out of unemployment. Using the basic monthly Current Population Survey from 2001-13 we match data for individuals who were interviewed in two consecutive months and identify workers who transition out of unemployment. We employ a multinomial model to examine the effects of immigration on the transition out of unemployment, using state-level immigration statistics. The results suggest that immigration does not affect the probabilities of native-born workers finding a job. Instead, we find that immigration is associated with smaller probabilities of remaining unemployed, but it is also associated with higher probabilities of workers leaving the labor force. This effect impacts mostly young and less educated people.
\end{abstract}

Keywords: Immigration; Unemployment Duration; Labor Force Transition

JEL Classifications: J1, J6 


\section{INTRODUCTION}

The immigration debate in the United States has a longstanding history (Orrenius and Zavodny 2012; Passel and Fix 1994). Over the last few decades the share of immigrants in the country has increased rapidly; according to official data, the share of foreign-born individuals in the US increased from 7.9\% in 1990 to almost 13.3\% in 2014, representing about 41.3 million people. Furthermore, from the total immigrant population, in 2014 about 11.3 million immigrants were estimated to be unauthorized immigrants (Passel and Cohn 2015). These trends have shaped the immigration policy in the US and motivated a large body of research focused on examining the economic impacts of immigration (Kerr and Kerr 2011).

The majority of the immigration research has been focused on analyzing the effects that immigrants, particularly unauthorized/illegal immigrants, have on the wages and employment opportunities of native-born workers (Okkerse 2008; Borjas 1999). The main concerns regarding immigration are based on the expectations that the arrival of immigrants would displace natives out of their jobs, while putting downward pressures on wages. These expectations are based on a standard competitive model of supply and demand in a closed economy (see for example, Borjas [1999]).

Despite the appeal of the theoretical framework and the anecdotal evidence connecting rising immigration rates with lower wages and higher unemployment, the research finds modest effects of immigration on the labor market opportunities of native-born workers. The large body of research finds that immigration has a negative and small, albeit statistically significant and consistent, impact on wages (Longhi, Nijkamp, and Poot 2005; Kerr and Kerr 2011); some have found a positive impact on productivity and wages (Hotchkiss, Quispe-Agnoli, and Rios Avila 2015; Peri 2010, 2012) with only a few studies showing evidence of larger negative effects of immigration (Borjas 2003; Altonji and Card 1991).

Regarding job displacement, most of the evidence suggests negative, but mostly small effects of immigration on employment (Longhi, Nijkamp, and Poot 2008). Similarly most of the evidence also indicates that unemployment rates do not seem to be affected by immigration in the 
aggregate, even among young and minority workers (Lucchino, Rosazza-Bondibene, and Portes 2012; Islam 2007; Shan 1999; Winter-Ebmer and Zweumuller 2000). Nevertheless, some of the literature (Card 2001; Frey 1996; Borjas 2003; Borjas, Grogger, and Hanson 2012) states that immigration significantly reduces employment and increases native-born workers’ outmigration.

While the literature on immigration effects on native-born workers has been broadly studied, little is known about the effects of immigration on the labor market opportunities of the unemployed. Unemployed workers are the group most likely to be affected by the presence of immigrants in their local labor markets, as they are actively competing for jobs. Thus, the unemployed individual's opportunities to find a job, their decision to continue searching for jobs, or decisions to exit the labor force are expected to be influenced by the effect immigration has on wages and on the availability of jobs in the labor market. Furthermore, even if immigration has no effect on job opportunities and wages in the aggregate, the presence of immigrants can have an effect on the expectations of wage trends and job opportunities in the labor market (Orrenious and Zavodny 2012; Anderson 2010; Mayda 2006; Scheve and Slaughter 2001), which can also affect the transition rates of unemployed workers.

Only a few papers have attempted to analyze the impact of immigration on unemployed workers in terms of unemployment duration. Using data for Australia, Winter-Ebmer and Zweumuller (2000) find that immigration has a positive impact on unemployment duration. Fromentin (2012), using aggregated panel data for OECD countries, finds that immigration increases shortterm unemployment but reduces long-term unemployment. To the best of our knowledge, there is no research for the US that has studied the impact of immigration on the labor market outcomes of unemployed native-born workers.

We contribute to the literature by examining the effects of immigration on unemployed nativeborn workers in the US. Based on an area analysis approach, we exploit the differences in the concentration of immigrants across states and time to identify the impact of immigration on native-born citizens' employment status changes, including their decisions to stay in the labor force. Using the basic monthly Current Population Survey (CPS) from 2001-13, we match data for individuals who were interviewed for two consecutive months and identify workers’ 
transitions out of unemployment. We employ a multinomial model to estimate the impact immigration has on the probability that an unemployed individual will continue being unemployed, find a job, leave the labor force, or decide to migrate. ${ }^{1}$

Our estimates suggest immigration has a small but statistically significant impact on native-born workers' transitions. We find that the probabilities of a native-born citizen finding a job are not affected by the share of immigrants in their labor market. Instead, we find that high levels of immigration are associated with smaller probabilities of remaining unemployed, contributing to shorter unemployment duration. Yet, the shorter unemployment spells are accompanied by higher probabilities of workers leaving the labor force, affecting mostly young and less-educated people. We also find that immigration does not seem to be related to the probability of nativeborn workers outmigrating. ${ }^{2}$

To the extent that immigration rates do not seem to be related to either lower or higher jobfinding probabilities in the sample, this can be interpreted as immigration having no effect on reducing employment opportunities for native-born workers. However, since an unemployed native-born citizen's probability of exiting the labor market increases with higher rates of immigration, this might suggest that native-born citizens become discouraged due to the presence of immigrants and leave the labor market. This can be interpreted as a response to expected labor market effects associated with immigration, job displacement, and lower wages, even if immigration has no direct effect on employment or wages. In other words, as unemployed native-born citizens' expectations about wages and job availability decline, they might reassess their situation and decide to leave the labor market instead continuing to look for jobs.

Similar to other findings in the literature, we find the immigration effects to be the highest among the youngest and least-educated native-born workers, who are the most likely to expect to be affected by low-skilled immigrants. We also find that native-born citizens who have Hispanic

\footnotetext{
${ }^{1}$ For this research the immigration rate is measured as the share of people $15+$ years of age who live in the same state, were born in a foreign country, and are not naturalized citizens.

${ }^{2}$ In this paper we assume that if an individual was not followed in the CPS from one month to the next, it was because he has moved to a different location.
} 
heritage or are children of immigrants seem not to be affected by immigration rates, as they are less likely to form negative expectations about the impact of immigration compared to other native-born citizens.

The rest of the paper is structured as follows. Section 2 presents a brief description of the immigration profile in the US. Sections 3 and 4 present a description of the data and the methodological approach. Section 5 concludes.

\section{ECONOMETRIC APPROACH}

The econometric approach used for the formal analysis of immigration on unemployment transitions in this paper is an application of a multinomial model and based on an area analysis approach that uses the differences in immigration rates across states and time to identify the effect of immigration on the labor market (Okkerse 2008: 7). For each observation in our data, conditional of an individual being unemployed at time $\mathrm{t}\left(s_{t}=U\right)$, we can model the probability of an individual changing their employment status $\left(s_{t+1}\right)$ from one month to another using a set of four independent logit models. Each equation characterizes the probability of transition from unemployment $\left(s_{t}=U\right)$ to finding a job $\left(s_{t+1}=E\right)$, remaining unemployed $\left(s_{t+1}=U\right)$, or leaving the labor force $\left(s_{t+1}=N\right)$. In addition, based on the arguments from Borjas (2005), we allow for internal migration of native-born workers by including a fourth option: leaving the sample possibly due to outmigration $\left(s_{t+1}=M\right)$ :

$$
\begin{aligned}
& p\left(s_{t+1}=E \mid s_{t}=U\right)=p_{e}=F\left(\gamma_{e} * I R+\alpha_{e} X\right) \\
& p\left(s_{t+1}=U \mid s_{t}=U\right)=p_{u}=F\left(\gamma_{u} * I R+\alpha_{u} X\right) \\
& p\left(s_{t+1}=N \mid s_{t}=U\right)=p_{n}=F\left(\gamma_{n} * I R+\alpha_{n} X\right) \\
& p\left(s_{t+1}=M \mid s_{t}=U\right)=p_{a}=F\left(\gamma_{a} * I R+\alpha_{a} X\right)
\end{aligned}
$$

where the immigration rate (IR) represents the percentage of immigrants as a share of the population living in a specific state in a given year and month, and $\mathrm{X}$ is a set of controls that affect the employment transitions probabilities of unemployed natives. $\mathrm{F}$ is the cumulative 
density function of a logistic distribution. In this framework, the parameter of interest is $\gamma_{i}$, as it indicates the direction in which the immigration rate (IR) affects the probabilities of remaining unemployed or changing employment status $\left(p_{e}, p_{u}, p_{n}, p_{m}\right)$. It is not difficult to see that equation (1b) can be intuitively used to analyze the effect that higher immigration rates have on unemployment duration, or more specifically, the effect it has on the risk of a worker remaining unemployed for one additional month.

In order to relax the assumption of independency on the unemployment transition outcomes, instead of modeling unemployment transitions using four separate equations, they can be estimated using a multinomial logit, where the probability of each transition out of unemployment can be written as a function that depends on all other states:

$$
p_{i}=\frac{\exp \left(\gamma_{i} * I R+\alpha_{i} X\right)}{\sum_{j=e, u, n, a} \exp \left(\gamma_{\left.j^{* I R}+\alpha_{j} X\right)}\right.} \text { for } i=e, u, n, m
$$

For identification, the multinomial model described in (2) requires that all coefficients of one of the transition statuses to be constant and equal to zero, although the marginal effects associated with the model are invariant to this choice. Here, the marginal effects associated with the immigration rate can be estimated as:

$$
\frac{\partial p_{i}}{\partial I R}=p_{i} *\left(\gamma_{i}-\sum_{j \neq i} p_{j} \gamma_{j}\right)
$$

In this model we identify the effect immigration has on transitions out of unemployment using the variation of immigration rates across states and time. Since we analyze unemployment transitions based on current unemployment status, we do not control for self-selection issues related to how individuals became unemployed. However, since we have data on unemployment duration, we are able to control for the impact of duration dependence on unemployment transitions. In this sense, the results provided here can only be extended to unemployed nativeborn individuals. 
Another feature of the model is that the estimated marginal effects (equation 3) provide an estimate for the net effect of immigration on the transition probabilities, in a comparative static set up. This implies that in the model we cannot identify the effects of how changes into one employment state affect the changes into other employment states. ${ }^{3}$

While the model estimated here does not discriminate as to whether an individual chooses or is pushed to be in one employment status or other, the implication for such movements needs attention. Transitions rates towards employment, for example, can be explained mostly by changes in job market conditions and job creation, and to a lesser extent individual decisions regarding job search and choosing to work. In a similar way, while remaining unemployed can be related to decisions on extending the job search period, it is also likely to be affected by market conditions, such as the unavailability of jobs. On the other hand, transitions out of the labor market or into migration are more directly related to personal decisions, even though they are indirectly affected by labor market conditions.

\subsection{Model Specification}

As described before, our dependent variable is a categorical variable that indicates the employment state in the following month of an individual who is unemployed at the time of the interview. Based on our specification, from one month to the other, individuals can be in one of three different employment statuses: employed, unemployed, or out of the labor force. Because native-born citizens can decide to migrate to a different location as one response to the presence of immigrants in the labor force (Pedace 1998; Card and Dinardo 2000; Peri 2007), we include in the analysis a category for observations without a match in our data. This category would allow us to capture potential outmigration effects of immigration, based on the assumption that the main cause for data not having a match is because the respondent moves from their current address (Madrian and Lefrge 2000).

For the main explanatory variable, we control for the state-level immigration rate (IR), which is measured as the share of people who are 15 years of age or older, living in a given state, who

\footnotetext{
${ }^{3}$ This implies that we cannot identify how an increase in the probability of leaving the labor force, ceteris paribus, affects the probability of finding a job.
} 
were born in a foreign country and declare they are not naturalized citizens. Given the large volatility of the measure, especially in states with low levels of immigration, we adjust the series using a 12-month window of data around the month of interest. ${ }^{4}$ This procedure allows for a more accurate measure of immigration within states, while preserving the long-run immigration trend.

As part of the explanatory variables we include sex, age, education, citizenship, and race to account for the differences in labor market opportunities workers with different characteristics exhibit. To capture the non-linearity associated with age and life cycle in the labor force, we control for age categories based on ten-year brackets (15-24, 25-34; 35-44, 55-64, and 64+), using the youngest workers as the omitted category. For education, we distinguish five education categories, including less than high school (omitted category), high school, some college, college, and graduate school education. Variables for race (black, Hispanic, or other) are also included to account for market discrimination.

We capture individual job search preferences by including indicators for civil status (married or separated) and relationship to the head. If an individual has bigger responsibilities as an income generator in the household, he/she would be more likely consider shorting their job search period (shorter unemployment spell) and be less inclined to leave the labor force. If they have a complementary role in the household, as in the case of children, they might be more inclined to leave the job market sooner. The household size and number of children under 13 years of age are also included in the controls to account for additional dimensions of the job market responsibilities and implicit costs of remaining in the labor force.

A very important factor to consider is to account for push and pull factors that could simultaneously affect the inflow (outflow) of immigrants into a local market, and at the same time the transition probabilities among the native-born unemployed population. In order to address this problem and reduce its potential impact on the estimates, we control for the effect of the business cycles and local labor market health using three different measures. First, we control

\footnotetext{
${ }^{4}$ For any given month, the share of immigrants in a state is calculated as the average of this share across five months before and five months after the month of interest, including the month of interest. This is similar to applying a local linear regression with a triangular weight on the data.
} 
for the seasonally adjusted unemployment rate at the state level, which is obtained from the Local Area Unemployment Statistics (LAUS) program. ${ }^{5}$ One would expect, other things held constant, that areas with a high unemployment rate might also have a slower job creation rate, affecting the likelihood of a worker transitioning out of unemployment. Second, following the research of Farber and Valletta (2015), we control for the log of the maximum number of weeks of unemployment insurance (UI) available in a state at a point in time. In addition, we also control for whether an individual unemployment spell is shorter than the maximum number of weeks of UI available in their state, which should better capture the effect of longer unemployment benefits. Both variables would control for whether or not more generous unemployment insurance benefits affect the probability of an individual remaining unemployed for an additional month. Lastly, we also include as controls a full set of state, year, and month dummies. This allows us to control for unobserved factors that are fixed within states, seasonal factors (month dummies), and overall business cycles (year) that we are not able to control otherwise.

Following the literature on duration models and survival analysis (Cameron and Trivedi 2005: ch 17), we account for the time dependence between the unemployment duration and transition rates by including dummies that indicate how long an individual has been unemployed in the current spell. We use "less than one month" as the base category, also identifying those unemployed over one month, two months, between three to five months, between six to eleven months, twelve to twenty-three months, and twenty-four months or more. This allows the capture of any non-linear relationship between unemployment duration.

\subsection{Immigration, Data Errors, and Survey Design}

As stipulated before, the rotating panel of the CPS provides a unique design in which individuals are followed for up to four consecutive months as long as they remain in the same residence. Each month, however, as shown in table 1, approximately 25\% percent of the data is left unmatched due to the design of the survey or data errors. If this feature of the data is related to the transition rates out of unemployment and the immigration rate, ignoring it could generate inconsistencies in the estimations of the model.

\footnotetext{
${ }^{5}$ More details on the data construction and access can be found at http://www.bls.gov/lau/home.htm.
} 
In order to account for the data loss due to data errors and survey design, as well as reduce the potential effects it could have on the estimations, we decide to treat both situations as a missing data problem. In this sense, we correct the potential bias by adjusting the sampling weights of the remaining sample using an inverse probability weighting (IPW) approach (Seaman and White 2011). Intuitively, this approach puts more weight on observations that have a lower probability of being missing, so that the effective sample is representative of the full sample. For its implementation, we estimate a multinomial logit where the dependent variable indicates if an observation was linked to a follow-up month $(\mathrm{d}=1)$, if it is not linked due to attrition/moving out of the house $(d=2)$, if it is left out of the sample due to data design $(d=3)$, or data errors $(d=4)$. As explanatory variables we use a set of individual, household, and labor market characteristics (including unemployment spell length) as independent variables. After the predicted probabilities are estimated, the sample weights for the relevant data are adjusted as follows: ${ }^{6}$

$$
w_{\text {adj }}=w_{\text {orig }} * \frac{1}{p_{d=1}+p_{d=2}}
$$

For the rest of the paper, the statistical analysis is based on the sample of observations with clear transitions out of unemployment, using the weight adjustment presented in equation 4 . Since the individuals are potentially observed multiple times in the data, we use the individual panel identifier to cluster the standard errors.

For the rest of the paper, we proceed with the analysis using the sample for which we observe a clear transition out of unemployment into employment, out of the labor force, remaining unemployed, or attrition (moving) using the adjusted weights.

\section{DATA AND SUMMARY STATISTICS}

\subsection{Data Description}

The study uses data from the CPS from 2001 to 2013, obtained from the Integrated Public Use Microdata Series (IPUMS). The CPS is a monthly household survey conducted jointly by the US

\footnotetext{
${ }^{6}$ In appendix 1 we present the summary statistics for the main sample before and after adjusting the survey weights.
} 
Census Bureau and the Bureau of Labor Statistics, and designed to be the primary source of labor force statistics in the US. Data for approximately 140,000 individuals living in 70,000 households is collected each month. One feature of the CPS survey is its rotating panel design. Each household in the data is interviewed for four consecutive months, is left out for eight, and interviewed again for additional four months.

Given this rotating panel design, at any given month, approximately $75 \%$ of the households are interviewed in the consecutive months. Thanks to this feature, individuals can be followed to analyze their short-term transition rates out of unemployment. For the purpose of this paper, we follow the methodology described in Drew, Flood, and Warren (2014) and Madrian and Lefgren (2000) in order to obtain month to month matched data.

As described in Drew, Flood, and Warren (2014), linking information across years is difficult, as the questions themselves might have changed, or the individual might have moved out of the household for some reason and is no longer followed. In addition, there can be some level of data error that will prevent the accurate matching of data from one month to another. Since the purpose of this research is to estimate transitions rates out of unemployment without putting emphasis on the stability of the employment status transition, we only link data for two consecutive months. $^{7}$

We concentrate the analysis on native-born workers (those born from American parents), who are 15 years of age or older, and declared to be currently unemployed but have been actively seeking a job in the last four weeks. In order to account for data errors, migration, and sample design, observations are classified in five groups. As can be seen in table 1, from a total of 613,000 individuals, about 149,000 cannot be matched because the data corresponds to individuals interviewed in months four and eight of their interview rotation and consecutive month data is not available.

\footnotetext{
${ }^{7}$ Later in the paper we use information for individuals interviewed for three months to assess the robustness of the results to spurious status changes.
} 
From the rest of the data, we are unable to match the data for about 30,000 observations.

According to Drew, Flood, and Warren (2014) and Madrian and Lefgren (2000), households or individuals within households might not be able to be linked from one month to another because they may refuse to participate in the survey or they might be unavailable, but most often because they may have moved to a different location (migrate). These individuals are included in the analysis to account for the possibility of a worker who decided to move to a different location in search of better job market opportunities. In order to improve the quality of the linked data, bad links are identified based on differences in characteristics such as sex, age, race, and relationship to the head (data errors) and based on the declared number of weeks of continuous unemployment (unemployment duration error), which accounts for about 10,000 observations. For the purpose of this research we concentrate only on observations that are fully matched and those not matched due to migration, ignoring those that are left due to design or data errors. This leaves us with 430,000 observations.

Table 1. Data Description by Employment Transition and Match Category

\begin{tabular}{|l|r|r|r|r|r|r|}
\hline & \multicolumn{5}{|c|}{ Transition } & \\
\hline Data Type & Employment & Unemployment & $\begin{array}{c}\text { Not in the } \\
\text { labor } \\
\text { force }\end{array}$ & Attrition & $\begin{array}{c}\text { Out of } \\
\text { sample }\end{array}$ & \begin{tabular}{c} 
Total \\
\hline Matched Data
\end{tabular} \\
\hline Unmatched: Migration & 89,332 & 220,438 & 91,799 & & & 401,569 \\
\hline Unmatched: Data errors & 1,044 & & & 29,363 & & 29,363 \\
\hline $\begin{array}{l}\text { Unmatched: Unemployment } \\
\text { Error }\end{array}$ & & 1,735 & 1,047 & & & 3,826 \\
\hline Months 4 \& 8 & & 5,432 & & & & 5,432 \\
\hline Total & & & & & 141,979 & 141,979 \\
\hline
\end{tabular}

Note: Data counts all observations for unemployed native-born citizens, aged 15+ years.

\subsection{Summary Statistics}

On average, across all years in the data, $52.3 \%$ of individuals who are currently unemployed remain unemployed for an additional month, 19.6\% end their unemployment spell by becoming employed, 21.3\% exit the labor force, and 6.8\% migrate. Looking at these transition rates across different levels of the immigration rate, however, suggests that there is little evidence that living in areas with a higher concentration of immigrants affects these transition rates substantially. However, individuals who left the labor force or migrate are more likely to live in areas with a higher concentration of immigrants. 
In the rest of table 2, the sample means of all the variables included in the duration analysis by transition state are presented, with the exception of the state, year, and month dummies. We observe that there are more women among people who exit the labor force. Similarly, we observe a larger share of younger workers among those who exit the labor market, followed up by those who migrate. We also observe that the oldest (65 and above) are more represented among those who leave the labor force, but less than those who migrate.

Workers with less than a high school education are more common among people who left the labor force, while workers with higher levels of education seem to be more inclined to remain unemployed or succeed at finding a job. We should also notice that there are more individuals with only high school education among those who migrate and those who remain unemployed. With respect to race, we observe that white unemployed workers have a larger presence among those who find a job, while black workers are overrepresented among those who leave the labor force or migrate.

In terms of household demographics, workers who have never been married (single) represent a larger share of the individuals who leave the labor force or migrate, while individuals who are heads of their households (or married to the household head) have a higher representation among those who remain in the labor force. Children are disproportionally more represented among people who left the labor force. In our data, individuals who left the labor force are also characterized as living in larger households or households with more children under the age of 13. When looking at labor market conditions, it is not surprising that workers who remain unemployed live in states with the highest unemployment rates and longer available weeks of unemployment insurance benefits, and at the same time those who become employed (column 1) are more likely to have been unemployed for a shorter time. 
Table 2. Summary Statistics Selected Variables

\begin{tabular}{|c|c|c|c|c|c|}
\hline & \multicolumn{4}{|c|}{ Transition rate from $\mathrm{U}$ in $\mathrm{t}$} & \multirow[b]{2}{*}{ Total } \\
\hline Immigration rate & $\mathrm{E}$ & $\mathrm{U}$ & NLF & $\mathrm{M}$ & \\
\hline $0-5 \%$ & 20.8 & 51.7 & 20.9 & 6.7 & 100 \\
\hline $5-10 \%$ & 19.0 & 53.4 & 20.9 & 6.7 & 100 \\
\hline $10-15 \%$ & 19.3 & 51.0 & 22.3 & 7.4 & 100 \\
\hline $15-20 \%$ & 17.5 & 54.3 & 21.8 & 6.4 & 100 \\
\hline \multirow[t]{2}{*}{ Total } & 19.6 & 52.3 & 21.3 & 6.8 & 100 \\
\hline & \multicolumn{5}{|c|}{ Sample means } \\
\hline \multicolumn{6}{|l|}{ Demographics } \\
\hline Immigration rate & 7.686 & 7.869 & 8.014 & 7.997 & 7.87 \\
\hline \multicolumn{6}{|l|}{ Sex } \\
\hline Men & $56.8 \%$ & $57.4 \%$ & $49.7 \%$ & $56.7 \%$ & $55.6 \%$ \\
\hline Women & $43.2 \%$ & $42.6 \%$ & $50.3 \%$ & $43.3 \%$ & $44.4 \%$ \\
\hline \multicolumn{6}{|l|}{ Age } \\
\hline $15-24$ & $33.5 \%$ & $27.1 \%$ & $44.8 \%$ & $38.8 \%$ & $32.9 \%$ \\
\hline $25-34$ & $22.4 \%$ & $22.4 \%$ & $17.7 \%$ & $27.3 \%$ & $21.7 \%$ \\
\hline $35-44$ & $17.8 \%$ & $18.7 \%$ & $12.8 \%$ & $16.1 \%$ & $17.1 \%$ \\
\hline $45-54$ & $15.5 \%$ & $18.4 \%$ & $12.0 \%$ & $11.8 \%$ & $16.0 \%$ \\
\hline $55-64$ & $8.5 \%$ & $10.9 \%$ & $8.4 \%$ & $4.7 \%$ & $9.4 \%$ \\
\hline $65+$ & $2.3 \%$ & $2.6 \%$ & $4.3 \%$ & $1.3 \%$ & $2.8 \%$ \\
\hline \multicolumn{6}{|l|}{ Education } \\
\hline Less than high school & $18.0 \%$ & $18.7 \%$ & $31.7 \%$ & $23.5 \%$ & $21.7 \%$ \\
\hline High school & $35.5 \%$ & $37.0 \%$ & $32.8 \%$ & $38.6 \%$ & $35.9 \%$ \\
\hline Some college & $29.6 \%$ & $28.2 \%$ & $25.2 \%$ & $26.1 \%$ & $27.7 \%$ \\
\hline College & $12.7 \%$ & $12.1 \%$ & $7.6 \%$ & $9.0 \%$ & $11.0 \%$ \\
\hline Grad school & $4.2 \%$ & $4.0 \%$ & $2.7 \%$ & $2.7 \%$ & $3.7 \%$ \\
\hline \multicolumn{6}{|l|}{ Race } \\
\hline White & $69.8 \%$ & $63.4 \%$ & $57.9 \%$ & $56.3 \%$ & $63.0 \%$ \\
\hline Black & $15.7 \%$ & $21.4 \%$ & $24.1 \%$ & $25.5 \%$ & $21.1 \%$ \\
\hline Other & $3.9 \%$ & $4.2 \%$ & $4.9 \%$ & $5.1 \%$ & $4.3 \%$ \\
\hline Hispanic & $10.6 \%$ & $11.0 \%$ & $13.1 \%$ & $13.2 \%$ & $11.5 \%$ \\
\hline \multicolumn{6}{|l|}{ Household Demographics } \\
\hline \multicolumn{6}{|l|}{ Civil status } \\
\hline Single & $49.5 \%$ & $48.3 \%$ & $60.0 \%$ & $59.3 \%$ & $51.8 \%$ \\
\hline Married & $34.9 \%$ & $33.2 \%$ & $25.9 \%$ & $22.4 \%$ & $31.2 \%$ \\
\hline Separated/divorce/widow & $15.7 \%$ & $18.5 \%$ & $14.1 \%$ & $18.2 \%$ & $17.0 \%$ \\
\hline \multicolumn{6}{|l|}{ Rel to $\mathrm{HH}$} \\
\hline Head or spouse & $63.1 \%$ & $65.9 \%$ & $50.1 \%$ & $58.7 \%$ & $61.5 \%$ \\
\hline Children & $28.5 \%$ & $27.0 \%$ & $41.2 \%$ & $26.3 \%$ & $30.3 \%$ \\
\hline Other & $8.4 \%$ & $7.1 \%$ & $8.7 \%$ & $15.0 \%$ & $8.2 \%$ \\
\hline Household Size & 3.19 & 3.08 & 3.40 & 3.14 & 3.17 \\
\hline \#Children 0-13 & 0.58 & 0.58 & 0.63 & 0.63 & 0.60 \\
\hline \multicolumn{6}{|l|}{ Labor market conditions } \\
\hline Unemployment rate & 6.78 & 7.54 & 7.13 & 7.10 & 7.27 \\
\hline \% Potential UI beneficiaries & $90.5 \%$ & $83.0 \%$ & $82.2 \%$ & $86.7 \%$ & $84.5 \%$ \\
\hline Log of max weeks of UI benefits & 3.78 & 3.94 & 3.85 & 3.85 & 3.88 \\
\hline
\end{tabular}




\begin{tabular}{|l|r|r|r|r|r|}
\hline Unemployment Duration & & & & & \\
\hline Less than 1 month & $31.8 \%$ & $13.9 \%$ & $20.0 \%$ & $21.3 \%$ & $19.2 \%$ \\
\hline $1-2$ months & $18.8 \%$ & $14.3 \%$ & $16.4 \%$ & $16.7 \%$ & $15.8 \%$ \\
\hline $2-3$ months & $12.5 \%$ & $11.8 \%$ & $12.2 \%$ & $13.1 \%$ & $12.1 \%$ \\
\hline $3-5$ months & $17.4 \%$ & $21.3 \%$ & $17.4 \%$ & $19.6 \%$ & $19.6 \%$ \\
\hline $6-11$ months & $10.5 \%$ & $17.3 \%$ & $14.1 \%$ & $13.8 \%$ & $15.1 \%$ \\
\hline $12-23$ months & $6.2 \%$ & $13.6 \%$ & $11.9 \%$ & $10.3 \%$ & $11.5 \%$ \\
\hline More than 24 months & $2.9 \%$ & $7.8 \%$ & $8.0 \%$ & $5.3 \%$ & $6.7 \%$ \\
\hline Number of observations & 89,332 & 220,438 & 91,799 & 29,363 & 430,932 \\
\hline
\end{tabular}

Note: Estimates based on CPS data from 2001 to 2013, and adjusted weights to deal with missing data. Sample is composed of unemployed native-born citizens, ages 15 and older.

\section{RESULTS}

Table 3 presents the average marginal effects corresponding to the multinomial logit model on the probability of transitioning out of unemployment in the baseline specification. In addition to the variables presented in the table 2, the models also control for state of residence, year, and month dummies. Based on the baseline estimation, on average, living in a state with a high concentration of immigrants reduces the probability of a worker remaining unemployed for an additional month. However, the shorter unemployment duration translates into higher probabilities of a worker leaving the labor force. Specifically, our baseline estimation suggests that if the immigration rate in a state increases by 1 percentage point, say from an average of $7.9 \%$ to $8.9 \%$, then the probability of an average worker remaining unemployed declines by $0.34 \%$, and his probability of leaving the labor force increases by $0.3 \%$. While the magnitude of the result is relatively small, it has important implications in terms of the impact of immigration on labor market dynamics.

First, the estimates suggest there is no evidence that living in an area with a higher concentration of immigrants affects the employment opportunities of native-born unemployed workers. In other words, any two unemployed native-born workers have the same probability of finding a job, regardless of how many immigrants are living in their state. This, however, does not imply that immigration has no effects on the availability of jobs or on the job displacement of nativeborn citizens. Second, the estimates also suggest that there is no evidence that living in a state with a higher concentration of immigrants changes the probability of an unemployed native-born 
citizen migrating (M), which is consistent with the findings in Peri (2012). This does not necessarily contradict the findings in Borjas (2003), Card and DiNardo (2000), and Frey (1996) because immigration may be increasing outmigration for native-born citizens who are "not in the labor force."

Third, based on the literature on perceptions of immigration and immigration's impacts on the labor market (Hainmuller and Hopkins 2014; Pecoraro and Ruedin 2015; Okkerse 2008; Longhi, Nijkamp, and Poot 2005), it is possible that the observed effect of immigration on the probability of leaving the labor force is driven by expectations associated with the impact immigration has on the labor market. ${ }^{8}$ On the one hand, if we start with the assumption that immigration has a large and negative effect on wages, as suggested by Borjas (2003), native-born workers will consider this expected decline in potential earnings and might decide to leave the labor force, as the cost of continuing to look for a job is larger than the benefits of continuing to search for a low-paying job. On the other hand, even if wages are not strongly affected by immigration, as most of the literature suggests, unemployed workers' behavior might still be affected in the same way if they believe immigration affects wages and the availability of jobs. In other words, as the proportion of immigrants increase in the local labor market, unemployed native-born workers could expect wages and the number of jobs available to decline, and would decide to leave the labor force.

Regarding the rest of the variables, they follow patterns similar to those observed elsewhere in the literature. In summary, women are less likely to find a job (-1.7\%), remain unemployed $(-3.9 \%)$, or migrate $(-0.6 \%)$, but far more likely to leave the labor force $(+6.2 \%)$. Across their life cycle, workers are more likely to remain unemployed as they grow older, as well as become less likely to find a job or migrate. For those 65 years of age and older (i.e., retirement age), they are much more likely $(+12.6 \%)$ to leave the labor force, but are just as likely as the youngest cohort to remain unemployed.

\footnotetext{
${ }^{8}$ As suggested by Anderson (2010) and Orrienous and Zavodny (2012), right or not, historically immigration has been blamed for society’s problems, including high unemployment and deteriorating wages.
} 
Higher levels of education increases the time a worker remains unemployed, possibly by increasing the search time for a good job, as well as increases their chances of finding a job. Higher education is also related to a lower probability of leaving the labor force or migration. In terms of race, compared to white workers, all other races are less likely to find a job, especially for black workers. Only black workers seem to be more likely to remain unemployed for an additional month. Compared to whites, all races are more likely to either leave the labor force or migrate.

Compared to being single, being married and thus having more responsibilities within a household is correlated with shorter unemployment spells, higher probability of finding a job, and lower likelihood of migration. However, those who are currently separated/divorced or widowed are less likely to leave the labor force, although they are also more likely to migrate. In terms of their role in the household, those who are identified as "other" members show lower probabilities of remaining unemployed (-5.9\%), but are more likely to leave the labor force or migrate. While children are less likely to find a job and more likely to leave the labor force, they are less inclined to migrate.

Regarding the structure of the household, people living in larger households seem to have shorter unemployment spells because they are more likely to exit the labor force, but also more likely to find a job. However, when considering the number of young children (ages 0-13), more children increase the probability of remaining unemployed and reduce the probability of being employed the next month. We do find that having more children has a small but positive impact on the probability of an unemployed worker migrating.

When looking at the indicators of the local labor market conditions, as it is expected, living in a state with higher unemployment rates increases the likelihood of a worker remaining unemployed, and reduces the probability of them being employed in the next period or leaving the labor force. Similar to Farber and Valletta (2015), we observe that if an individual can potentially benefit from the insurance, he has a lower probability of exiting the labor market. We also observe they are more likely to remain unemployed (possibly investing more time in searching for a better job) and have a higher probability of migrating. 
Finally, regarding the unemployment duration dependence, it can be observed that the longer workers are unemployed, the lower their chances of finding a job and the higher their chances of remaining unemployed for an additional month. In addition, it seems that workers who have been unemployed for more than one year might become discouraged and are more likely to leave the labor force. For all duration levels, the results suggest that compared to those recently unemployed, all other individuals are less likely to migrate. In aggregate, these results suggest that the longer native-born citizens are unemployed, the less employable and less attached to the labor market they become (Krueger, Cramer, and Cho 2014).

Table 3. Multinomial Transition Model: Average Marginal Effects

\begin{tabular}{|c|c|c|c|c|}
\hline & $\mathrm{E}$ & $\mathrm{U}$ & NLF & M \\
\hline & 19.6 & 52.3 & 21.3 & 6.8 \\
\hline Immigration rate & $\begin{array}{l}0.0003 \\
(0.0011)\end{array}$ & $\begin{array}{l}-0.0034^{* *} \\
(0.0014)\end{array}$ & $\begin{array}{l}0.0030 * * * \\
(0.0011)\end{array}$ & $\begin{array}{l}0.0002 \\
(0.0007)\end{array}$ \\
\hline Female & $\begin{array}{l}-0.0167^{* * *} \\
(0.0014)\end{array}$ & $\begin{array}{l}{ }^{k}-0.0391 * * * \\
(0.0019)\end{array}$ & $\begin{array}{l}{ }^{k} 0.0621 * * * \\
(0.0015)\end{array}$ & $\begin{array}{l}-0.0063^{* * *} \\
(0.0009)\end{array}$ \\
\hline \multicolumn{5}{|l|}{ Age group } \\
\hline $25-34$ & $\begin{array}{l}-0.0008 \\
(0.0022)\end{array}$ & $\begin{array}{l}0.0643 * * * \\
(0.0030)\end{array}$ & $\begin{array}{l}-0.0577 \text { *** } \\
(0.0024)\end{array}$ & $\begin{array}{c}*-0.0059 \text { *** } \\
(0.0014)\end{array}$ \\
\hline $35-44$ & $\begin{array}{l}-0.0072^{* * *} \\
(0.0025)\end{array}$ & $\begin{array}{l}{ }^{k} 0.0935^{* * * *} \\
(0.0034)\end{array}$ & $\begin{array}{l}-0.0595^{* * *} \\
(0.0028)\end{array}$ & $\begin{array}{c}{ }^{*}-0.0267 * * * \\
(0.0016)\end{array}$ \\
\hline $45-54$ & $\begin{array}{l}-0.0206 * * * \\
(0.0028)\end{array}$ & $\begin{array}{l}{ }^{*} 0.1112^{* * *} \\
(0.0037)\end{array}$ & $\begin{array}{l}-0.0464 * * * \\
(0.0031)\end{array}$ & $\begin{array}{c}*-0.0442 * * * \\
(0.0019)\end{array}$ \\
\hline 55-64 & $\begin{array}{l}-0.0364 * * * \\
(0.0033)\end{array}$ & $\begin{array}{l}{ }^{k} 0.1041^{* * *} \\
(0.0043)\end{array}$ & $\begin{array}{l}0.0037 \\
(0.0035)\end{array}$ & $\begin{array}{l}-0.0714^{* * *} \\
(0.0025)\end{array}$ \\
\hline $65-79$ & $\begin{array}{l}-0.0522^{* * *} \\
(0.0049)\end{array}$ & $\begin{array}{l}0.0042 \\
(0.0066)\end{array}$ & $\begin{array}{l}0.1258^{* * *} \\
(0.0046)\end{array}$ & $\begin{array}{l}-0.0779 * * * \\
(0.0040)\end{array}$ \\
\hline \multicolumn{5}{|l|}{ Education attainment } \\
\hline High school & $\begin{array}{l}0.0399 * * * \\
(0.0020)\end{array}$ & $\begin{array}{l}0.0294 * * * \\
(0.0026)\end{array}$ & $\begin{array}{l}-0.0698 * * * \\
(0.0019)\end{array}$ & $\begin{array}{c}* 0.0005 \\
(0.0012)\end{array}$ \\
\hline Some college & $\begin{array}{l}0.0542^{* * *} \\
(0.0021)\end{array}$ & $\begin{array}{l}0.0204 * * * \\
(0.0028)\end{array}$ & $\begin{array}{l}-0.0677^{* * *} \\
(0.0021)\end{array}$ & $\begin{array}{c}*-0.0070 * * * \\
(0.0014)\end{array}$ \\
\hline College degree & $\begin{array}{l}0.0697 * * * \\
(0.0027)\end{array}$ & $\begin{array}{l}0.0496 * * * \\
(0.0037)\end{array}$ & $\begin{array}{l}-0.1101^{* * *} \\
(0.0030)\end{array}$ & $\begin{array}{c}{ }^{*}-0.0092 * * * \\
(0.0019)\end{array}$ \\
\hline Grad school & $\begin{array}{l}0.0706^{* * *} \\
(0.0039)\end{array}$ & $\begin{array}{l}0.0342^{* * *} \\
(0.0054)\end{array}$ & $\begin{array}{l}-0.0985^{* * *} \\
(0.0045)\end{array}$ & $\begin{array}{c}*-0.0063 * * \\
(0.0029)\end{array}$ \\
\hline \multicolumn{5}{|l|}{ Race } \\
\hline Black & $\begin{array}{l}-0.0533 * * * \\
(0.0021)\end{array}$ & $\begin{array}{l}0.0087 * * * \\
(0.0027)\end{array}$ & $\begin{array}{l}0.0296 * * * \\
(0.0021)\end{array}$ & $\begin{array}{l}0.0150 * * * \\
(0.0012)\end{array}$ \\
\hline Other & $\begin{array}{l}-0.0341 * * * \\
(0.0036)\end{array}$ & $\begin{array}{l}{ }^{k}-0.0015 \\
(0.0047)\end{array}$ & $\begin{array}{l}0.0256 * * * \\
(0.0036)\end{array}$ & $\begin{array}{l}0.0100 * * * \\
(0.0021)\end{array}$ \\
\hline Hispanic & $\begin{array}{l}-0.0200^{* * *} \\
(0.0025)\end{array}$ & $\begin{array}{l}{ }^{k} 0.0004 \\
(0.0033)\end{array}$ & $\begin{array}{l}0.0133 * * * \\
(0.0026)\end{array}$ & $\begin{array}{l}0.0063 * * * \\
(0.0016)\end{array}$ \\
\hline
\end{tabular}




\begin{tabular}{|c|c|c|c|c|}
\hline \multicolumn{5}{|l|}{ Marital status } \\
\hline Married & $\begin{array}{l}0.0231^{* * *} \\
(0.0022)\end{array}$ & $\begin{array}{l}-0.0088 * * * \\
(0.0029)\end{array}$ & $\begin{array}{l}0.0003 \\
(0.0024)\end{array}$ & $\begin{array}{l}-0.0146^{* * *} \\
(0.0015)\end{array}$ \\
\hline Sep/div/widow & $\begin{array}{l}0.0073 * * * \\
(0.0024)\end{array}$ & $\begin{array}{l}0.0004 \\
(0.0031)\end{array}$ & $\begin{array}{l}-0.0204 * * * \\
(0.0026)\end{array}$ & $\begin{array}{l}0.0127 * * * \\
(0.0015)\end{array}$ \\
\hline \multicolumn{5}{|l|}{ Relationship to the head } \\
\hline Children & $\begin{array}{l}-0.0235^{* * *} \\
(0.0024)\end{array}$ & $\begin{array}{l}-0.0091 * * * \\
(0.0031)\end{array}$ & $\begin{array}{l}0.0622 * * * \\
(0.0025)\end{array}$ & $\begin{array}{l}-0.0296 * * * \\
(0.0015)\end{array}$ \\
\hline Other & $\begin{array}{l}-0.0050 * \\
(0.0029)\end{array}$ & $\begin{array}{l}-0.0592 * * * \\
(0.0039)\end{array}$ & $\begin{array}{l}0.0337 * * * \\
(0.0031)\end{array}$ & $\begin{array}{l}0.0305^{* * *} \\
(0.0016)\end{array}$ \\
\hline Household size & $\begin{array}{l}0.0081^{* * *} \\
(0.0008)\end{array}$ & $\begin{array}{l}-0.0135 * * * \\
(0.0011)\end{array}$ & $\begin{array}{l}0.0108 * * * \\
(0.0008)\end{array}$ & $\begin{array}{l}-0.0054^{* * *} \\
(0.0005)\end{array}$ \\
\hline Number of children, ages $0-13$ & $\begin{array}{l}-0.0137 * * * \\
(0.0011)\end{array}$ & $\begin{array}{l}{ }^{k} 0.0132 * * * \\
(0.0015)\end{array}$ & $\begin{array}{l}-0.0017 \\
(0.0012)\end{array}$ & $\begin{array}{l}0.0022 * * * \\
(0.0007)\end{array}$ \\
\hline State unemp rate & $\begin{array}{l}-0.0092 * * * \\
(0.0009)\end{array}$ & $\begin{array}{l}0.0169 * * * \\
(0.0012)\end{array}$ & $\begin{array}{l}-0.0066 * * * \\
(0.0010)\end{array}$ & $\begin{array}{l}-0.0010 * \\
(0.0006)\end{array}$ \\
\hline wks unemp $<$ max UI weeks & $\begin{array}{l}-0.0161^{* * *} \\
(0.0035)\end{array}$ & $\begin{array}{l}0.0241^{* * *} \\
(0.0042)\end{array}$ & $\begin{array}{l}-0.0134 * * * \\
(0.0033)\end{array}$ & $\begin{array}{l}0.0054 * * \\
(0.0021)\end{array}$ \\
\hline Log (weeks UI benefits) & $\begin{array}{l}-0.0058 \\
(0.0050)\end{array}$ & $\begin{array}{l}-0.0074 \\
(0.0065)\end{array}$ & $\begin{array}{l}0.0067 \\
(0.0054)\end{array}$ & $\begin{array}{l}0.0065^{* *} \\
(0.0033)\end{array}$ \\
\hline \multicolumn{5}{|l|}{ Unemployment duration } \\
\hline 1 month & $\begin{array}{l}-0.0671^{* * *} \\
(0.0020)\end{array}$ & $\begin{array}{l}0.0790 * * * \\
(0.0028)\end{array}$ & $\begin{array}{l}-0.0055^{* *} \\
(0.0023)\end{array}$ & $\begin{array}{l}-0.0064^{* * *} \\
(0.0014)\end{array}$ \\
\hline 2 months & $\begin{array}{l}-0.0930 * * * \\
(0.0022)\end{array}$ & $\begin{array}{l}0.1074 * * * \\
(0.0030)\end{array}$ & $\begin{array}{l}-0.0093^{* * *} \\
(0.0025)\end{array}$ & $\begin{array}{l}-0.0050 * * * \\
(0.0015)\end{array}$ \\
\hline 3-5 months & $\begin{array}{l}-0.1176^{* * *} \\
(0.0020)\end{array}$ & $\begin{array}{l}0.1501^{* * *} \\
(0.0028)\end{array}$ & $\begin{array}{l}-0.0243^{* * *} \\
(0.0023)\end{array}$ & $\begin{array}{l}-0.0082^{* * *} \\
(0.0014)\end{array}$ \\
\hline 6-11 months & $\begin{array}{l}-0.1587 * * * \\
(0.0027)\end{array}$ & $\begin{array}{l}0.1740 * * * \\
(0.0033)\end{array}$ & $\begin{array}{l}-0.0071^{* * *} \\
(0.0028)\end{array}$ & $\begin{array}{l}-0.0081 * * * \\
(0.0017)\end{array}$ \\
\hline 12-23 months & $\begin{array}{l}-0.1986 * * * \\
(0.0035)\end{array}$ & $\begin{array}{l}0.1860 * * * \\
(0.0040)\end{array}$ & $\begin{array}{l}0.0175^{* * *} \\
(0.0032)\end{array}$ & $\begin{array}{l}-0.0049 * * \\
(0.0020)\end{array}$ \\
\hline 2 or more years & $\begin{array}{l}-0.2383 * * * \\
(0.0055)\end{array}$ & $\begin{array}{l}0.1981 * * * \\
(0.0063)\end{array}$ & $\begin{array}{l}0.0472 * * * \\
(0.0049)\end{array}$ & $\begin{array}{l}-0.0070 * * \\
(0.0032)\end{array}$ \\
\hline Observations & 430932 & 430932 & 430932 & 430932 \\
\hline
\end{tabular}

Note: ${ }^{*} \mathrm{p}<0.1,{ }^{* *} \mathrm{p}<0.05,{ }^{* * *} \mathrm{p}<0.01$. Clustered standard errors using adjusted weights in parenthesis. Model includes state, year, and month marginal effects.

\subsection{Heterogeneity of Immigration Effects}

Most of the literature on the economic impact of immigration suggests that it depends on the degree of substitutability or complementarity between citizen and immigrant workers (Peri 2007; Ottaviano and Peri 2012; Borjas, Grogger, and Hanson 2012). This implies that there could be some heterogeneity in the effects of immigration depending on the characteristics of native-born workers, as they might be more likely to be affected by the presence of immigrants who are similar to them in terms of their skill characteristics. We explore this possibility by modifying the baseline specification introducing interactions of the immigration rate measure with 
demographic characteristics including sex, age, and education. These estimates are presented in table 4.

The first aspect to observe is the potential heterogeneity across gender. The results suggest that there are no heterogeneous effects of immigration across gender. Similar to the baseline results, we observe no evidence that higher immigration rates affect the probability of finding a job or of migrating. We also see that the estimates show small differences regarding the probability of leaving the labor force, with a somewhat smaller probability of women remaining unemployed.

The second aspect of interest is to look across different age groups. Since immigrants (in particular unauthorized/undocumented immigrants) tend to be younger (Passel and Cohn 2015), it is possible that younger native-born workers are the most affected by the presence of immigrants in their labor markets. For example, the work from Smith (2012) and Sum, Harrington, and Khatiwada (2006) suggest that young workers have been the most affected by the presence of immigration in their local markets. Looking at the estimations, and consistent with the literature, we observe that younger workers are affected the most by the presence of immigrants, as they show the largest marginal effects, decreasing the probability of remaining unemployed but increasing the probability of leaving the labor force. Older cohorts show relatively smaller marginal effects in regards to immigration. For the oldest unemployed workers, immigration seems to have a negative, albeit statistically significant effect (at 10\%), reducing their probability of finding a job.

The closest measure of skill in our data is workers' education level. In terms of wages, most of the literature has found that immigration has the largest negative impacts on low-skilled nativeborn workers (Altonji and Card 1991; Card 2001). There is also evidence suggesting that the presence of highly skilled immigrants can reduce the wages of highly skilled native-born workers (Borjas 2005; Borjas, Grogger, and Hanson 2012), although others show that immigration has a rather positive impact on native-born workers' labor outcomes (Ottaviano and Peri 2012). Overall, and consistent with the main results, the estimates interacting education level suggests that overall immigration has no impact on the probability of finding a job or migrating, increases the probability of leaving the labor force, and reduces the probability of 
remaining unemployed for an additional month. The results also suggest that the marginal effects are smaller for unemployed native-born citizens with higher education. For instance, unemployed native-born citizens with a college degree are not significantly affected by the immigration rate, and the observed effect on the unemployment probability is significant only at the $10 \%$ level of confidence.

These observed effects in regards to education and age can be explained to the extent that immigrants, particularly those perceived to be unauthorized immigrants, are characterized as being younger and less educated (Passel and Cohn 2015). In this sense, the estimated effects are explained either because of the additional labor market competition with the highly substitutable labor (immigrants), or because younger and less-educated native-born citizens have the most negative expectations in regards to the impact of immigrants in the labor market. 
Table 4. Transition Model: Heterogeneous Effects across Demographics, Marginal Effects

\begin{tabular}{|c|c|c|c|c|}
\hline & \multicolumn{4}{|c|}{$\begin{array}{l}\text { Interactions } \\
\text { Transition to }\end{array}$} \\
\hline & $E$ & $\mathrm{U}$ & $\mathrm{NLF}$ & $\mathrm{M}$ \\
\hline \multicolumn{5}{|l|}{ Sex } \\
\hline IR $x$ male & $\begin{array}{l}-0.0001 \\
(0.0011)\end{array}$ & $\begin{array}{l}-0.0029 * * \\
(0.0014)\end{array}$ & $\begin{array}{l}0.0029 * * * \\
(0.0010)\end{array}$ & $\begin{array}{l}0.0001 \\
(0.0007)\end{array}$ \\
\hline IR x female & $\begin{array}{l}0.0006 \\
(0.0010)\end{array}$ & $\begin{array}{l}-0.0040^{* * *} \\
(0.0014)\end{array}$ & $\begin{array}{l}0.0031^{* *} \\
(0.0013)\end{array}$ & $\begin{array}{l}0.0003 \\
(0.0007)\end{array}$ \\
\hline \multicolumn{5}{|l|}{ Age } \\
\hline IR x 15-24 & $\begin{array}{l}0.0002 \\
(0.0011)\end{array}$ & $\begin{array}{l}-0.0038^{* * *} \\
(0.0014)\end{array}$ & $\begin{array}{l}0.0037 * * * \\
(0.0012)\end{array}$ & $\begin{array}{l}-0.0001 \\
(0.0007)\end{array}$ \\
\hline IR x 25-44 & $\begin{array}{l}0.0006 \\
(0.0011)\end{array}$ & $\begin{array}{l}-0.0031^{* *} \\
(0.0014)\end{array}$ & $\begin{array}{l}0.0023 * * \\
(0.0011)\end{array}$ & $\begin{array}{l}0.0003 \\
(0.0007)\end{array}$ \\
\hline IR x 45-64 & $\begin{array}{l}-0.0002 \\
(0.0011)\end{array}$ & $\begin{array}{l}-0.0029^{* *} \\
(0.0015)\end{array}$ & $\begin{array}{l}0.0018 \\
(0.0012)\end{array}$ & $\begin{array}{l}0.0013 \\
(0.0008)\end{array}$ \\
\hline IR $x$ 65+ & $\begin{array}{l}-0.0022 * \\
(0.0013) \\
\end{array}$ & $\begin{array}{l}0.0001 \\
(0.0018)\end{array}$ & $\begin{array}{l}0.0007 \\
(0.0013)\end{array}$ & $\begin{array}{l}0.0013 \\
(0.0012) \\
\end{array}$ \\
\hline \multicolumn{5}{|l|}{ Education } \\
\hline IR $x$ less than HS & $\begin{array}{l}0.0001 \\
(0.0011)\end{array}$ & $\begin{array}{l}-0.0034^{* *} \\
(0.0014)\end{array}$ & $\begin{array}{l}0.0031^{* * *} \\
(0.0012)\end{array}$ & $\begin{array}{l}0.0001 \\
(0.0007)\end{array}$ \\
\hline IR x high school & $\begin{array}{l}0.0003 \\
(0.0011)\end{array}$ & $\begin{array}{l}-0.0039^{* * *} \\
(0.0014)\end{array}$ & $\begin{array}{l}0.0035^{* * * *} \\
(0.0012)\end{array}$ & $\begin{array}{l}0.0001 \\
(0.0007)\end{array}$ \\
\hline IR x some college & $\begin{array}{l}0.0001 \\
(0.0011)\end{array}$ & $\begin{array}{l}-0.0031^{* *} \\
(0.0015)\end{array}$ & $\begin{array}{l}0.0025^{* *} \\
(0.0012)\end{array}$ & $\begin{array}{l}0.0006 \\
(0.0007)\end{array}$ \\
\hline IR x college+ degree & $\begin{array}{l}0.0009 \\
(0.0011)\end{array}$ & $\begin{array}{l}-0.0026^{*} \\
(0.0015)\end{array}$ & $\begin{array}{l}0.0016 \\
(0.0012)\end{array}$ & $\begin{array}{l}0.0000 \\
(0.0007)\end{array}$ \\
\hline Observations & 430932 & 430932 & 430932 & 430932 \\
\hline
\end{tabular}

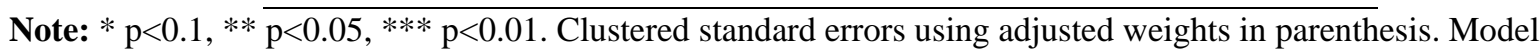
includes state, year, and month marginal effects.

\subsection{Robustness to Data Design}

Up to this point we have shown that higher rates of immigration reduce the probability of a worker remaining unemployed, but increase the likelihood of them leaving the labor force (see table 5, M0). Because of the composition of the sample, the survey design, and the broad identification of immigration, it is possible that the model is not providing consistent estimates of the impact of immigration on the labor market transition probabilities. In this section, we provide additional estimates to test the robustness of the findings.

The first aspect to consider is the robustness of the results to the sample selection and survey design. As indicated in the methodological section, we control for the impact of data error and observations that drop due to data design by adjusting the sample weights using an inverse probability weighting approach. While the strategy is meant to correct the bias due to unobserved 
outcomes, there is a possibility that we may have introduced other sources of biases on the data. In row M1 of table 5 we present estimates using the original sample weights and observe that the weight adjustment did not introduce any unforeseen bias to the estimates.

One potential problem in our identification strategy is the presence of outliers. Specifically, the State of California, which represents just over $8 \%$ of the data in the sample, is characterized as having the largest immigration rates in the country at $18.1 \%$, followed by Texas at $13 \%$. Even though we control for labor market conditions and state fixed effects, the high immigration rate and sample representation of these two states in the data can potentially bias the results. As shown in row M2, excluding data from California and Texas has little effect on the estimates, with marginal effects somewhat larger than those of the baseline model (M0).

Another common argument with regards to the sample is the inclusion of younger (younger than $25)$ and older cohorts (65+) in the sample of analysis. Although younger workers have been shown to be the most likely to be affected by the presence of immigrants, people under 25 are more likely to be transitioning between work and school, and therefore might not be the best population to accurately estimate our models. Similarly, because older cohorts are more likely to be retired, including them might bias the results. The parameters obtained based on a sample of unemployed native-born workers between 25-64 years of age (row M3) suggests that the results are robust to this sample specification.

A source of possible bias in the analysis is the effect that of long-term unemployment has on our results. Between 2001 and 2010, the design of the CPS allowed individuals to declare up to two years of continuous unemployment. Starting in January of 2011 (and reflected in the public access data after April of that year), due to the increase in people declaring they were unemployed for longer periods of time during and after the Great Recession, individuals are able to indicate unemployment spells of up to five years. While our specification accounts for the unemployment duration dependence of unemployed individuals' transitions, the heterogeneity in the distribution of the transition rates of people who have been unemployed for more than two years can potentially introduce a bias into the estimates, as they would be far more likely to become discouraged or remain unemployed. In row M4 we provide estimates excluding people 
who have been unemployed for more than two years, and observe the marginal effects are effectively similar to the baseline results.

An important consideration in the terms of data design is the influence of the timing of the survey. As indicated before, the CPS collects information from individuals for up to four consecutive months, before and after the eight-month break. In 1994, the CPS went through a redesign that allowed for the use of computer-assisted interviewing and the use of dependent interviewing. This feature enabled the use of data reported in previous rounds to be confirmed or updated in subsequent months (US Census Bureau 2006). If the information collected from individuals in later rounds is systematically different from that in earlier rounds, due to the timesensitive nature of unemployment duration, it might create inconsistent results. In row M5 we explore this potential problem by including interactions between the immigration rate and the month in sample (MIS) round in the baseline specification. Our estimates indicate that overall conclusions from the estimates do not change; however we do observe that the marginal effects of immigration on transition probabilities decline for observations of individuals that come from later interview rounds.

As described in Farber and Valletta (2015), one important factor to consider for the validity of the analysis is the potential presence of spurious transitions out of unemployment, which can lead to underestimations of the probability of remaining unemployed, and biases in the estimates of our model. Based on Farber and Valletta (2015) and Rothstein (2011) we address this problem by recategorizing the transition rates of individuals who we observed to have transitioned out of unemployment in the following month, but are again classified as unemployed two months later. Since we required to constrain the data to people who were interviewed for at least three consecutive months, our sample is cut from 430,000 observations to 358,000, and the probability of remaining unemployed increases from $52 \%$ to $59 \% .{ }^{9}$ While the results are robust to using this correction to the dependent variable, we observe that the impact on the probability of individuals leaving the labor force is about $30 \%$ smaller than that observed in the baseline.

\footnotetext{
${ }^{9}$ The estimates use the baseline adjusted weights, which do not adjust for the additional data loss.
} 
Table 5. Marginal Effects of Immigration: Robustness to Sample Design

\begin{tabular}{|c|c|c|c|c|}
\hline & \multicolumn{4}{|c|}{ Transition to } \\
\hline & $\mathrm{E}$ & $\mathrm{U}$ & NLF & $\mathrm{M}$ \\
\hline M0: Baseline & $\begin{array}{l}0.0003 \\
(0.0011)\end{array}$ & $\begin{array}{l}-0.0034 * * \\
(0.0014)\end{array}$ & $\begin{array}{l}0.0030 * * * \\
(0.0011)\end{array}$ & $\begin{array}{l}0.0002 \\
(0.0007)\end{array}$ \\
\hline M1: Uses original weights & $\begin{array}{l}0.0003 \\
(0.0011)\end{array}$ & $\begin{array}{l}-0.0035^{* *} \\
(0.0014)\end{array}$ & $\begin{array}{l}0.0030 * * * \\
(0.0011)\end{array}$ & $\begin{array}{l}0.0001 \\
(0.0007)\end{array}$ \\
\hline $\begin{array}{l}\text { M2: Excludes } \\
\text { California and Texas }\end{array}$ & $\begin{array}{l}0.0008 \\
(0.0013)\end{array}$ & $\begin{array}{l}-0.0040 * * \\
(0.0017)\end{array}$ & $\begin{array}{l}0.0035 * * \\
(0.0014)\end{array}$ & $\begin{array}{l}-0.0003 \\
(0.0008)\end{array}$ \\
\hline M3: Using sample 25-64 & $\begin{array}{l}-0.0005 \\
(0.0012)\end{array}$ & $\begin{array}{l}-0.0029 * \\
(0.0016)\end{array}$ & $\begin{array}{l}0.0029 * * \\
(0.0012)\end{array}$ & $\begin{array}{l}0.0006 \\
(0.0008)\end{array}$ \\
\hline $\begin{array}{l}\text { M4: Excludes long-term } \\
\text { unemployment ( } 2+\text { years) }\end{array}$ & $\begin{array}{l}0.0007 \\
(0.0011)\end{array}$ & $\begin{array}{l}-0.0039 * * * \\
(0.0015)\end{array}$ & $\begin{array}{l}0.0028 * * \\
(0.0012)\end{array}$ & $\begin{array}{l}0.0004 \\
(0.0007)\end{array}$ \\
\hline M5: Interacting with MIS & & & & \\
\hline $\mathrm{IR} *(\mathrm{mis}=1 \mid \mathrm{mis}=5)$ & $\begin{array}{l}-0.0002 \\
(0.0010)\end{array}$ & $\begin{array}{l}-0.0042^{* * *} \\
(0.0014)\end{array}$ & $\begin{array}{l}0.0040 * * * \\
(0.0012)\end{array}$ & $\begin{array}{l}0.0004 \\
(0.0007)\end{array}$ \\
\hline IR * (mis=2 | mis=6) & $\begin{array}{l}0.0007 \\
(0.0011)\end{array}$ & $\begin{array}{l}-0.0036 * * \\
(0.0014)\end{array}$ & $\begin{array}{l}0.0026^{* *} \\
(0.0011)\end{array}$ & $\begin{array}{l}0.0003 \\
(0.0007)\end{array}$ \\
\hline IR * (mis=3 | mis=7) & $\begin{array}{l}0.0003 \\
(0.0011)\end{array}$ & $\begin{array}{l}-0.0024^{*} \\
(0.0014)\end{array}$ & $\begin{array}{l}0.0022^{* *} \\
(0.0011)\end{array}$ & $\begin{array}{l}-0.0001 \\
(0.0007)\end{array}$ \\
\hline $\begin{array}{l}\text { M6: Robust to spurious transition } \\
\text { IR }\end{array}$ & $\begin{array}{l}0.0007 \\
(0.0011)\end{array}$ & $\begin{array}{l}-0.0032 * * \\
(0.0015)\end{array}$ & $\begin{array}{l}0.0021 * \\
(0.0011)\end{array}$ & $\begin{array}{l}-0.0004 \\
(0.0007)\end{array}$ \\
\hline
\end{tabular}

Note: ${ }^{*} \mathrm{p}<0.1,{ }^{* *} \mathrm{p}<0.05,{ }^{* * *} \mathrm{p}<0.01$. Clustered standard errors using adjusted weights in parenthesis. Model includes state, year, and month marginal effects.

\subsection{Expectations and Immigration}

One of the potential channels through which immigration affects transition rates out of unemployment is through the role of the expectations that unemployed workers have regarding the effect of immigration on wages and the availability of jobs. If unemployed workers expect wages for potential jobs to decline, and further expect the availability of jobs to decrease, they might reassess their situation and leave the labor market (also known as the "discouraged worker effect"; see Ehrenberg and Smith [2015: ch7]). Even if wages and employment availability are not affected by immigration, unemployed workers may still change their behavior if they believe immigration will have such effects (Orrenious and Zavodny 2012; Anderson 2010; Mayda 2006; Scheve and Slaughter 2001). In this section we provide some evidence that suggests that 
negative expectations about the impact of immigration on labor market outcomes, in particular unauthorized immigration, are the main drivers of the observed effect.

The first aspect under consideration in table 6 is to analyze the effect the immigration rate has on the transition probabilities of populations less likely to have pessimistic expectations due to immigration. In our data we identify three different samples that fulfill these criteria: naturalized citizens (22,867 observations), individuals with immigrant parents (77,095 observations), and individuals who identify as having Hispanic heritage (41,919 observations). These groups are expected to have a more neutral view of immigrants, thus they might have no expectations regarding lower wages or employment, as they were immigrants at some point or they are directly related to an immigrant (Suro 2005; Rouse, Wilkinson, and Garand 2010). Based on our hypothesis, if the immigration rate affects the labor force exit rates because of the pessimistic expectations toward immigration, populations without these expectations will be less likely to modify their behavior as a function of immigration rates.

In table 6, we present estimates of the model using the sample of foreign-born citizens (M7), citizens with Hispanic heritage (declared to be Hispanic) (M8), citizens with a foreign-born parent (M9), and a combination of all samples (M10). The results suggest that immigration rates at the state level have no effect on the transition probabilities of these subpopulations. This could mean that these individuals are not affected by immigration because they might not have negative expectations with regard to their labor market opportunities, as compared to other native-born workers’ expectations.

In addition to these models, in row M11, we estimate the model using a sample that excludes the observations from models M7 to M9. This sample is composed of unemployed individuals who have the fewest ties with immigration, and as such the most likely to have negative expectations regarding their labor market opportunities in the presence of immigration. As expected, the estimates are consistent with the hypothesis, and the marginal effects are comparable with those of the baseline. 
Another aspect of immigration and its perception among unemployed native-born workers can be linked to the type of immigration itself. While there is a relatively general consensus that illegal immigration has a detrimental impact on the economy, in particular for low-skilled workers, there is less research regarding the impact of authorized immigrants. Nevertheless, since legal immigrants and naturalized immigrants are more likely to have better human capital, earn higher wages, and are more likely to promote economic growth (Peri 2012, 2010), one would expect that they have a more positive (or less negative) expected impact on wages and jobs in the labor market. Under the assumption that native-born citizens are able distinguish between different types of immigrants, if legal immigration is perceived as a lesser threat than unauthorized immigration, then we would expect measures capturing legal immigration to have a smaller (if any) effect on the transition probabilities. Even if native-born workers are not able to distinguish between immigrants, their behavior might still respond to the signals in the labor market in terms of changes in wages and employment availability.

To test this hypothesis, we create three additional measures of immigration, based on their potential legal status in the country. First, we create a share of naturalized immigrants, which is measured as the share of all foreign-born individuals, ages 15 years and above, who self-identify as naturalized citizens. Second, based on the work of Passel and Cohn (2015), which provides a description of unauthorized immigrants in the US, we identify a share of individuals who are likely unauthorized immigrants as a proportion of foreign-born non-citizens, between 20-45 years of age, with at most high school education and from Hispanic origin. Finally, we create an immigration rate of likely authorized immigrants, which is defined as the difference between overall immigration (which excludes naturalized citizens) and the share of likely unauthorized immigrants. The biggest challenge of this analysis is that it is hard to correctly identify the presence of illegal immigrants, as they would be less willing to be captured in survey data such as the CPS. However, to the extent that our measure captures the overall trends of total unauthorized immigration, the identification of the effect would still be valid.

If unemployed native-born citizens expect naturalized citizens and likely authorized immigrants to be less of a threat for their job market opportunities compared to unauthorized immigrants, we would expect the transition rates to be unaffected by these measures of immigration. Instead, we 
should only see the measure of unauthorized immigration affecting the transition probabilities. In rows M12, M13, and M14, we present the marginal effects of three different specifications that include the alternative immigration rates. Row M12 suggests that the share of naturalized citizens has no statistically significant effect on any of the transition rates. Row M13 also corroborates our hypothesis, as only the rate of unauthorized immigration is significantly associated with lower probabilities of remaining unemployed, and larger probabilities of leaving the labor force. Finally in row M14, we include all three immigration rates and find the same results as in M12 and M13, which indicate that neither the share of naturalized immigrants, nor the share of likely authorized immigrants has any effect on the transition probabilities. 
Table 6. Marginal Effects of Immigration: Immigration and Perception

\begin{tabular}{|c|c|c|c|c|}
\hline & \multicolumn{4}{|c|}{ Transition to } \\
\hline & $E$ & $\mathrm{U}$ & NLF & A \\
\hline $\begin{array}{l}\text { M7: Sample of foreign-born } \\
\text { citizens }\end{array}$ & $\begin{array}{l}-0.0046 \\
(0.0039)\end{array}$ & $\begin{array}{l}0.0007 \\
(0.0054)\end{array}$ & $\begin{array}{l}0.0030 \\
(0.0043)\end{array}$ & $\begin{array}{l}0.0009 \\
(0.0023)\end{array}$ \\
\hline M8: Sample of Hispanic heritage & $\begin{array}{l}-0.0026 \\
(0.0029)\end{array}$ & $\begin{array}{l}0.0011 \\
(0.0040)\end{array}$ & $\begin{array}{l}0.0006 \\
(0.0033)\end{array}$ & $\begin{array}{l}0.0008 \\
(0.0021)\end{array}$ \\
\hline M9: Sample of first generation & $\begin{array}{l}-0.0044 \\
(0.0031)\end{array}$ & $\begin{array}{l}0.00003 \\
(0.0043)\end{array}$ & $\begin{array}{l}0.0026 \\
(0.0036)\end{array}$ & $\begin{array}{l}0.0018 \\
(0.0021)\end{array}$ \\
\hline $\begin{array}{l}\text { M10: Sample of first generation } \\
\text { and Hispanic heritage }\end{array}$ & $\begin{array}{l}-0.0007 \\
(0.0021)\end{array}$ & $\begin{array}{l}-0.0009 \\
(0.0028)\end{array}$ & $\begin{array}{l}0.0016 \\
(0.0023)\end{array}$ & $\begin{array}{l}-0.0000 \\
(0.0014)\end{array}$ \\
\hline M11: Sample excluding Hispanic or first gen & $\begin{array}{l}0.0010 \\
(0.0012)\end{array}$ & $\begin{array}{l}-0.0041^{* *} \\
(0.0017)\end{array}$ & $\begin{array}{l}0.0033^{* *} \\
(0.0013)\end{array}$ & $\begin{array}{l}-0.0002 \\
(0.0008)\end{array}$ \\
\hline M12:Modifying immigration $n$ & & & & \\
\hline Share of naturalized citizens & $\begin{array}{l}0.0013 \\
(0.0015)\end{array}$ & $\begin{array}{l}0.0012 \\
(0.0020)\end{array}$ & $\begin{array}{l}-0.0020 \\
(0.0016)\end{array}$ & $\begin{array}{l}-0.0005 \\
(0.0010)\end{array}$ \\
\hline IR w/o naturalized citizens & $\begin{array}{l}0.0005 \\
(0.0011)\end{array}$ & $\begin{array}{l}-0.0030^{* *} \\
(0.0015)\end{array}$ & $\begin{array}{l}0.0025^{* *} \\
(0.0012)\end{array}$ & $\begin{array}{l}0.0000 \\
(0.0007)\end{array}$ \\
\hline M13:Authorized and unauthorized immigrants & & & & \\
\hline $\begin{array}{l}\text { IR likely unauthorized immigrants } \\
\text { (per Passel and Cohn 2015) }\end{array}$ & $\begin{array}{l}0.0005 \\
(0.0014)\end{array}$ & $\begin{array}{l}-0.0045^{* *} \\
(0.0019)\end{array}$ & $\begin{array}{l}0.0033^{* *} \\
(0.0015)\end{array}$ & $\begin{array}{l}0.0007 \\
(0.0009)\end{array}$ \\
\hline IR likely authorized immigrants & $\begin{array}{l}0.0000 \\
(0.0017)\end{array}$ & $\begin{array}{l}-0.0020 \\
(0.0022)\end{array}$ & $\begin{array}{l}0.0027 \\
(0.0018)\end{array}$ & $\begin{array}{l}-0.0007 \\
(0.0011)\end{array}$ \\
\hline M14: M12 \& & & & & \\
\hline Share of naturalized citizens & $\begin{array}{l}0.0012 \\
(0.0015)\end{array}$ & $\begin{array}{l}0.0019 \\
(0.0020)\end{array}$ & $\begin{array}{l}-0.0022 \\
(0.0016)\end{array}$ & $\begin{array}{l}-0.0008 \\
(0.0010)\end{array}$ \\
\hline IR likely authorized immigrants & $\begin{array}{l}0.0005 \\
(0.0017)\end{array}$ & $\begin{array}{l}-0.0013 \\
(0.0023)\end{array}$ & $\begin{array}{l}0.0018 \\
(0.0019)\end{array}$ & $\begin{array}{l}-0.0010 \\
(0.0011)\end{array}$ \\
\hline $\begin{array}{r}\text { IR likely unauthorized immigrants } \\
\text { (per Passel and Cohn 2015) }\end{array}$ & $\begin{array}{l}0.0005 \\
(0.0014)\end{array}$ & $\begin{array}{l}-0.0042^{* *} \\
(0.0019) \\
\end{array}$ & $\begin{array}{l}0.0030^{* *} \\
(0.0015)\end{array}$ & $\begin{array}{l}0.0007 \\
(0.0009) \\
\end{array}$ \\
\hline
\end{tabular}

Note: ${ }^{*} \mathrm{p}<0.1,{ }^{* *} \mathrm{p}<0.05,{ }^{* * *} \mathrm{p}<0.01$. Clustered standard errors using adjusted weights in parenthesis. Model includes state, year, and month marginal effects.

\section{CONCLUSION}

In this paper we have explored the effects that immigration has on the labor market outcomes of unemployed citizens in the US. We concentrated our interest on unemployed individuals, as they potentially are the most likely to be affected by the presence of immigrants when searching for jobs in the labor market. 
Based on our estimations, our evidence suggests that immigration has no effect on the availability of jobs for unemployed citizens, and no observable effects on the probability of attrition, which is related to the outmigration effect described in the literature. On the other hand, while the marginal effects are small, we do find that citizens living in states with high levels of immigration are less likely to remain unemployed for an additional month, but are more likely to leave the labor force. We suggest that the main driving force of this effect is the expectation that immigration lowers wages and reduces the number of jobs available in the job market. This creates a discouraged worker effect, pushing people who would otherwise have remained unemployed out of the labor force.

In support of our hypothesis, we find three additional pieces of evidence. First, we find that young and less educated unemployed citizens (the most likely to face competition against immigration) are also the most affected by the presence of immigrants in their labor market. Second, individuals who have some type of connection to immigrants, first-generation citizens, or individuals with Hispanic heritage do not seem to be affected by the presence of immigration. And third, only illegal immigration is found to be related to the observed differences in the transition rates out of unemployment and out of the labor force. 


\section{REFERENCES}

Altonji, J.G., and D. Card. 1991. "The Effects of Immigration on the Labor Market Outcomes of Less-skilled Natives.” In J.M. Abowd and R.B. Freeman (eds.), Immigration, Trade, and the Labor Market, National Bureau of Economic Research Project Report. Chicago: University of Chicago Press.

Anderson, S. 2010. “Let's Not Blame Immigrants for High Unemployment Rates.” Immigration Reform Bulletin, no. 6. Washington, DC: Cato Institute.

Borjas, G. 1999. “The Economic Analysis of Immigration.” In O. Ashenfelter and D. Card (eds.), Handbook of Labor Economics. Amsterdam: North-Holland Elsevier Science.

— 2003. "The Labor Demand Curve Is Downward Sloping: Reexamining the Impact of Immigration on the Labor Market.” Quarterly Journal of Economics 118(4): 1335-74.

—. 2005 "The Labor-Market Impact of High-Skill Immigration.” American Economic Review 95(2): 56-60.

— 2006. "Native Internal Migration and the Labor Market Impact of Immigration.” The Journal of Human Resources 41(2): 221-58.

Borjas, G.J., J. Grogger, and G. Hanson. 2012. “Comment: On Estimating Elasticities of Substitution.” Journal of the European Economic Association 10(1): 198-210.

Cameron, A.C., and P.K. Trivedi. 2005. Microeconometrics: Methods and Applications. Cambridge: Cambridge University Press.

Card, D. 2001. "Immigrant Inflows, Native Outflows, and the Local Labor Market Impacts of Higher Immigration." Journal of Labor Economics 19(1): 22-64.

Card, D., and J. DiNardo. 2000. “Do Immigrant Inflows Lead to Native Outflows?” American Economic Review 90(2): 360-67.

Drew, J., S. Flood and J.R. Warren. 2014. "Making full use of the longitudinal design of the Current Population Survey: Methods for linking records across 16 months.” Journal of Economic and Social Measurement 39: 121-44.

Ehrenberg, R.G., and R.S. Smith. 2015. Modem Labor Economics: Theory and Public Policy, 12th ed. Boston: Addison Wesley Press.

Farber, H., and R. Valletta. 2015. "Do extended Unemployment benefits lengthen unemployment spells? Evidence from recent cycles in the US labor market.” Journal of Human Resources 50(4): 873-909. 
Frey, W.H. 1996. "Immigration, Domestic Migration, and Demographic Balkanization in America: New Evidence for the 1990s.” Population and Development Review 22(4): 741-63.

Fromentin, V. 2012. "Migration and unemployment duration in OECD countries: A dynamic panel analysis.” Economics Bulletin 32(2): 1113-24.

Hainmueller, J., and D.J. Hopkins. 2014. "Public Attitudes toward Immigration.” Annual Review of Political Science 17(May): 225-49.

Hotchkiss, J.L., M. Quispe-Agnoli, and F. Rios-Avila. 2015. “The Wage Impact of Undocumented Workers: Evidence from Administrative Data.” Southern Economic Journal 81(4): 874-906.

Islam, A. 2007. "Immigration Unemployment Relationship: The Evidence from Canada.” Australian Economic Papers 46(1): 52-66.

Kerr, S.P., and W.R. Kerr. 2011. “Economic Impacts of Immigration: A Survey.” Finnish Economic Papers 24(1): 1-32.

Krueger, A., J. Cramer, and D. Cho. 2014. “Are Long Term Unemployed on the Margins of the Labor Market?” Brookings Papers on Economic Activity Spring: 229-280.

Longhi, S., P. Nijkamp, and J. Poot. 2005. “A Meta-analytic Assessment of the Effect of Immigration on Wages.” Journal of Economic Surveys 19(3): 451-77.

—. 2008. "The Impact of Immigration on the Employment of Natives in Regional Labour Markets: A Meta-Analysis.” In J. Poot, B. Waldorf, and L. van Wissen (eds.), Migration and Human Capital. Cheltenham: Edward Elgar.

Lucchino, P., C. Rosazza-Bondibene, and J. Portes. 2012. "Examining the Relationship between Immigration and Unemployment Using National Insurance Number Registration Data.” NIESR Discussion Paper No. 36. London: National Institute of Economic and Social Research.

Madrian, B.C., and L. Lefgren. 2000. “An Approach to Longitudinally Matching Current Population Survey (CPS) Respondents.” Journal of Economic and Social Measurement 26(1): 31-62.

Mayda, A. M. 2006. "Who Is Against Immigration? A Cross-Country Investigation of Individual Attitudes toward Immigrants.” Review of Economics and Statistics 88(3): 510-30.

Okkerse, L. 2008. “How to Measure Labour Market Effects of Immigration: A Review.” Journal of Economic Surveys 22(1): 1-30. 
Orrenius, P., and M. Zavodny. 2012. "The Economics of U.S. Immigration Policy.” Journal of Policy Analysis and Management 31(4): 948-56.

Ottaviano, G.I.P., and G. Peri. 2005. "Rethinking the Gains from Immigration: Theory and Evidence from the US.” NBER Working Paper 11672. Cambridge, MA: National Bureau of Economic Research.

—. 2012. "Rethinking the Effect of Immigration on Wages." Journal of the European Economic Association 10(1): 152-97.

Passel, J.S., and D. Cohn. 2015. "Unauthorized Immigrant Population Stable for Half a Decade.” Washington, DC: Pew Research Center.

Passel, J.S., and M. Fix. 1994. “Myths about Immigrants.” Foreign Policy 95(1994): 151-60.

Pecoraro, M., and D. Ruedin. 2015. “A Foreigner Who Doesn’t Steal My Job: The Role of Unemployment Risk and Values in Attitudes towards Equal Opportunities.” International Migration Review, April 29. doi: 10.1111/imre.12162.

Pedace, R. 1998 "The Impact of Immigration on the Labor Market for Native-born Workers: Incorporating the Dynamics of Internal Migration.” Eastern Economic Journal 24(4): $449-62$.

Peri, G. 2007. "Immigrants’ Complementarities and Native Wages: Evidence from California.” NBER Working Paper 12956. Cambridge, MA: National Bureau of Economic Research.

- 2010. "The Effect of Immigrants on US Employment and Productivity.” FRBSF Economic Letter 2010-26. San Francisco: Federal Reserve Bank of San Francisco.

— 2012. "The Effect of Immigration on Productivity: Evidence from US States." Review of Economics and Statistics 94: 348-58.

Peri, G., and C. Sparber. 2009. “Task Specialization, Immigration, and Wages.” American Economic Journal: Applied Economics 1(3): 135-69.

Rothstein, J. 2011. "Unemployment insurance and job search in the Great Recession.” Brookings Papers on Economic Activity (Fall): 143-96.

Rouse, S.M., B.C. Wilkinson, and J.C. Garand. 2010. "Divided Loyalties? Understanding Variation in Latino Attitudes toward Immigration.” Social Science Quarterly 91(3): 85682.

Scheve, K.F., and M.J. Slaughter. 2001. "Labor Market Competition and Individual Preferences over Immigration Policy.” Review of Economics and Statistics 83(1): 133-45. 
Seaman, S.R., and I.R. White. 2011. "Review of inverse probability weighting for dealing with missing data.” Statistical Methods in Medical Research 22(3): 278-95.

Shan, J. 1999. “Immigration and Unemployment: New Evidence from Australia and New Zealand.” International Review of Applied Economics 13(2): 253-60.

Smith, C. 2012. “The Impact of Low-skilled Immigration on the Youth Labor Market.” Journal of Labor Economics 30(1): 55-89.

Sum, A., P. Harrington, and I. Khatiwada. 2006. “The Impact of New Immigrants on Young Native-born Workers, 2000-2005.” Backgrounder report. Washington, DC: Center for Immigration Studies.

Suro, R. 2005. "Attitudes toward Immigrants and Immigration Policy: Surveys among Latinos in the US and Mexico.” Washington, DC: Pew Hispanic Center.

US Census Bureau. 2006. “Current Population Survey: Design and Methodology.” Technical Paper 66. Washington, DC: U.S. Census Bureau. Available at: http://www.census.gov/prod/2006pubs/tp-66.pdf

Winter-Ebmer, R., and J. Zweimüller. 2000. "Consequences of Trade Creation and Increased Immigration for the Austrian Labour Market.” In M. Landesmann and K. Pichelmann (eds.), Unemployment in Europe. Basingstoke: Macmillan.

Winegarden, C., and L. Khor. 1991. "Undocumented Immigration and Unemployment of US Youth and Minority Workers: Econometric Evidence.” The Review of Economics and Statistics 73(1): 105-12. 


\section{APPENDIX 1}

\begin{tabular}{|c|c|c|c|c|}
\hline & $\begin{array}{l}\text { Sample } \\
\text { Org. We }\end{array}$ & Out of Sample & Total & \begin{tabular}{|l} 
Sample \\
Adj Weights
\end{tabular} \\
\hline \multicolumn{5}{|l|}{ Demographics } \\
\hline Immigration rate & 7.87 & 7.88 & 7.87 & 7.87 \\
\hline \multicolumn{5}{|l|}{ Sex } \\
\hline Men & $55.4 \%$ & $56.1 \%$ & $55.6 \%$ & $55.6 \%$ \\
\hline Women & $44.6 \%$ & $43.9 \%$ & $44.4 \%$ & $44.4 \%$ \\
\hline \multicolumn{5}{|l|}{ Age } \\
\hline $15-24$ & $33.1 \%$ & $32.4 \%$ & $32.9 \%$ & $32.9 \%$ \\
\hline $25-34$ & $21.7 \%$ & $21.7 \%$ & $21.7 \%$ & $21.7 \%$ \\
\hline $35-44$ & $17.0 \%$ & $17.3 \%$ & $17.1 \%$ & $17.1 \%$ \\
\hline $45-54$ & $16.0 \%$ & $16.0 \%$ & $16.0 \%$ & $16.0 \%$ \\
\hline $55-64$ & $9.4 \%$ & $9.6 \%$ & $9.4 \%$ & $9.4 \%$ \\
\hline $65+$ & $2.7 \%$ & $3.0 \%$ & $2.8 \%$ & $2.8 \%$ \\
\hline \multicolumn{5}{|l|}{ Education } \\
\hline Less than high school & $21.8 \%$ & $21.5 \%$ & $21.7 \%$ & $21.7 \%$ \\
\hline High school & $35.9 \%$ & $36.0 \%$ & $35.9 \%$ & $35.9 \%$ \\
\hline Some college & $27.7 \%$ & $27.7 \%$ & $27.7 \%$ & $27.7 \%$ \\
\hline College & $11.0 \%$ & $11.1 \%$ & $11.0 \%$ & $11.0 \%$ \\
\hline Grad school & $3.7 \%$ & $3.7 \%$ & $3.7 \%$ & $3.7 \%$ \\
\hline \multicolumn{5}{|l|}{ Race } \\
\hline White & $62.9 \%$ & $63.1 \%$ & $63.0 \%$ & $63.0 \%$ \\
\hline Black & $21.2 \%$ & $21.0 \%$ & $21.1 \%$ & $21.1 \%$ \\
\hline Other & $4.4 \%$ & $4.3 \%$ & $4.3 \%$ & $4.3 \%$ \\
\hline Hispanic & $11.5 \%$ & $11.5 \%$ & $11.5 \%$ & $11.5 \%$ \\
\hline \multicolumn{5}{|l|}{ Civil status } \\
\hline Single & $51.9 \%$ & $51.6 \%$ & $51.8 \%$ & $51.8 \%$ \\
\hline Married & $31.2 \%$ & $31.3 \%$ & $31.2 \%$ & $31.2 \%$ \\
\hline Separated/divorce/widow & $17.0 \%$ & $17.1 \%$ & $17.0 \%$ & $17.0 \%$ \\
\hline
\end{tabular}




\section{Household demographics}

Rel to $\mathrm{HH}$

Head or spouse

Children

Other

Household size

\#Children, ages 0-13

Unemployment duration

Less than 1 month

1-2 months

2-3 months

3-5 months

6-11 months

12-23 months

$61.6 \%$

$61.1 \%$

$61.5 \%$

$61.5 \%$

$30.3 \%$

$30.2 \%$

$30.3 \%$

$30.3 \%$

$8.1 \%$

$8.8 \%$

$8.2 \%$

$8.2 \%$

3.18

3.16

3.17

3.17

0.60

0.59

0.60

More than 24 months

$19.6 \%$

$18.2 \%$

$19.2 \%$

$19.2 \%$

$16.0 \%$

$15.0 \%$

$15.8 \%$

$15.8 \%$

$12.3 \%$

$11.5 \%$

$12.1 \%$

$12.1 \%$

$19.0 \%$

$21.3 \%$

$19.6 \%$

$19.6 \%$

$14.9 \%$

$15.6 \%$

$15.0 \%$

$15.1 \%$

$11.4 \%$

$12.0 \%$

$11.5 \%$

$11.5 \%$

Number of observations

$6.8 \%$

$6.4 \%$

$6.7 \%$

$6.7 \%$

430932

151237

582169

430932

Note: Summary statistics based on weighted data before and after applying the inverse probability weight correction. 